\title{
Effect of detergents from laundry greywater on soil properties: a preliminary study
}

\author{
R. M. Mohamed ${ }^{1}$ (1) - A. A. Al-Gheethi ${ }^{1}$ J. Noramira ${ }^{1}$ - C. M. Chan ${ }^{2}$ - M. K. Amir Hashim ${ }^{1}$ - M. Sabariah ${ }^{1}$
}

Received: 3 January 2017 / Accepted: 5 January 2018 / Published online: 24 January 2018

(c) The Author(s) 2018. This article is an open access publication

\begin{abstract}
Detergent compounds are classes of the organic micro-pollutants in the laundry wastewater. The disposal of these compounds into the soil has several adverse effects on their composition. In the present study, changes in the soil characteristics, which included saturated hydraulic conductivity $\left(K_{\text {sat }}\right), \mathrm{EC}, \mathrm{pH}$, exchangeable sodium percentage, cation exchange capacity (CEC), and sodium adsorption on ratio were examined after the irrigation with laundry wastewater. Ten clothes were washed with one full cap of powder (PLD) and liquid laundry (LLD). Laundry greywater samples were used for the irrigation of soil. The results revealed that the $\mathrm{pH}$ of soil increased from 3.85 to 4.42 and 4.09 after irrigation by PLD and LLD greywater, respectively. The EC of the irrigated soil increased from 50.32 to 152.5 and $147.6 \mu \mathrm{S} / \mathrm{cm}$, respectively. The CEC was raised to 79.93 and $41.39 \mathrm{meq} / 100 \mathrm{~g}$, while $K_{\text {sat }}$ was reduced to $7.38 \times 10^{-10}$ and $7.11 \times 10^{-10} \mathrm{~cm} / \mathrm{s}$, respectively. These findings highlighted the negative effects of laundry greywater discharge on soil properties.
\end{abstract}

Keywords Laundry greywater $\cdot$ Hydraulic conductivity $\cdot$ CEC $\cdot$ ESP $\cdot K_{\text {sat }}$

\section{Introduction}

Greywater is defined as the generated wastewater from household activities, which include bathroom, showers, laundry, and kitchen but not black water from the toilet. The percentage of greywater generated from household activities represents $50-80 \%$ of the total water usage; among these wastes, the laundry greywater represents up to $33 \%$ (Mohamed et al. 2014a, b). The main composition of laundry greywater are cations such as, $\mathrm{Ca}, \mathrm{Mg}, \mathrm{K}$, nitrate, sulphate anions, carbonate, and chloride as well as organic micropollutants (OMPs) resulting from the detergents (Mohamed

Electronic supplementary material The online version of this article (https://doi.org/10.1007/s13201-018-0664-3) contains supplementary material, which is available to authorized users.

R. M. Mohamed

maya@uthm.edu.my; adel@uthm.edu.my

1 Micropollutant Research Centre (MPRC), Department of Water and Environmental Engineering, Faculty of Civil and Environmental Engineering, Universiti Tun Hussein Onn Malaysia, Batu Pahat, 86400 Parit Raja, Johor, Malaysia

2 Department of Civil Engineering Technology, Faculty of Engineering Technology, Universiti Tun Hussein Onn Malaysia, Batu Pahat, 86400 Parit Raja, Johor, Malaysia et al. 2013a, 2014b; Chan et al. 2014). In order to limit the adverse effects of laundry greywater on the environment, as well as avoiding the occurrence of eutrophication in the water bodies which received these wastes, phosphate-free detergents were introduced in 1986 (Jacob and Wirtschaftsforschung 2005). However, laundry greywater still has many OMPs which have high persistence in the environment. Eriksson et al. (2003) revealed that the greywater in Denmark contained more than 200 types of OMPs which included plasticizers, surfactants, antioxidants, fragrances, and dyes. Ying (2006) reported that the bathing greywater contains high concentration of surfactants.

Surfactants (surface active agents) represent the major OMPs in the greywater because they are used in the generation of detergents and hygiene products, which are utilized extensively in bathing and clothes' washing. The surfactants included the compounds generated from amphoteric, cationic, anionic and nonionic detergents. These classes also encompass anionic and cationic surfactants such as methylestersulphonate, olefinsulphonate, alkyl benzene sulphonates, alkyl ether sulphates, isotridecanolethoxylates, benzalkonium chloride, $n$-hexadecyltrimethy, and ammonium chloride. The utilization of these detergents is dependent on their potential to provide cleaning action, disinfection 
agents, and the low price (Jakobi and Lohr 1987; Lange 1994; Belanger et al. 2002).

In developing countries, the disposal of greywater into soil drainage is a common practice. However, these practices have become unacceptable in many of the developed countries due to the distribution of pollutants such as chemical agents, OMPs, and pathogens into the natural water and soil and then the transmission into the human via food chain. Besides, the high salinity of laundry greywater which is derived from detergents is a major concern. The determination of soil salinity is used to assess the presence or absence of the adverse effects resulting from the utilization of greywater in the irrigation. The level of salinity is quantified based on the sodium adsorption ratio (SAR) index (Lazarova and Asano 2005). The SAR in laundry greywater might reach $12.32 \mathrm{mg} \mathrm{L}^{-1}$ which results from the utilization of detergent with concentrations of $3000 \mathrm{mg} \mathrm{L}^{-1}$ (Abu-Zreiget al. 2003). It has demonstrated that the increase of SAR causes a decrease in saturated hydraulic conductivity $\left(K_{\text {sat }}\right)$ in the soil (Gross et al. 2008). The irrigation of soil with greywater contains high levels of sodium $(\mathrm{Na})$, which causes degradation of the soil composition and permeability.

Another negative effect of soil irrigated with the untreated greywater is the elevation in $\mathrm{pH}$ values due to the high contents of alkaline detergents (Travis et al. 2010; Sivongxay 2005). The laundry greywater of $\mathrm{pH} 9$ and above acts as a dispersing agent which causes soil particles to split and lead to the increase of soil cation exchange capacity (CEC) (Sivongxay 2005; Anwar 2011).

It was revealed that the properties of sandy soil changed after being irrigated with surfactant-rich laundry greywater (Anwar 2011). Understanding the effect of detergents on the soil properties can potentially assist in designing a proper management for the laundry wastewater disposal or reuse in the irrigations. The local governments in Australia are strongly considering the application of greywater (generated from laundries and bathrooms) as an option for irrigating household lawns and gardens, therefore, reducing the demand for filtered water (Mohamed et al. 2013a).

The present study was performed to assess the negative effects of discharged laundry greywater on the soil characteristics and the impact on the soil chemistry and its infiltration in Batu Pahat, Johor, Malaysia. This study aimed to assess the untreated effluent of detergents from laundry greywater on the soil properties.

\section{Materials and methods}

\section{Study area and sampling}

Seven soil samples (one sample/week) were collected from Parit Rajazone (coordinate E103'06'14.1'), which is approximately $10 \mathrm{~km}$ from Batu Pahat town in Johor, Malaysia. The samples were collected between March and May 2015 (dry season in Malaysia). The study area was selected because the laundry greywater is a direct discharge into the soil (Online Appendix A). The soil sampling point was chosen at an undisturbed land where there is no human activity recorded to avoid effects resulting from human activities. The samples were collected from several mixed subsamples by first eliminating the top $10-15 \mathrm{~cm}$ of top soil and the samples were dug for $30 \mathrm{~cm}$ depth of soil by using a clean spade in accordance with the procedure described by Misra and Sivongxay (2009) without incorporating any modifications. The samples were transported to a laboratory in firmly sealed polyethylene bags. Thereafter, the samples were subjected to air-drying and were passed through a 2-mm mesh sieve before being stored in polyethylene bags for subsequent tests.

The characteristics of soil samples including $\mathrm{pH}$ and electrical conductivity (EC) were tested according to BS 1377 : Part 3 (1990). The chemical properties of soil and water which included cation exchange capacity (CEC), exchangeable sodium percentage (ESP), and sodium adsorption ration (SAR) were analysed using X-ray fluorescence (XRF) and atomic absorption spectroscopy (AAS).

\section{Collection of laundry greywater}

Two detergents were used in the washing process of clothes and production of laundry greywater. The detergents were powdered laundry detergent (Bio Zip) (PLD) and liquid laundry detergent (Dynamo) (LLD). The detergents were selected because they are the dominant brands used in the study area based on the information gathered from the local community members during the collection of soil samples. The powder and liquid laundry detergents were prepared according to the manufacturers' instructions. A fix of ten clothes was placed in an automatic washing machine (Panasonic, Model NA-F65B2) and one full cap of each detergent was added. The laundry greywater generated after the first, second, and third wash was collected and used to irrigate the examined soil samples.

\section{Experimental set-up of hydraulic conductivity}

Hydraulic conductivity experiments were performed according to Darcy's Law calculation as described by Misra and Sivonghay (2009). Three soil cores were carried out in replicates for each laundry greywater. The soil core was constructed with fine cloth, duct tape, filter paper, and PVC pipe (Online Appendix B). In order to prevent mass loss and escape of suspended solids which are less than $\leq 2.0 \mu \mathrm{m}$ in size, the fine cloth was positioned above the PVC pipe tube. The system was locked tightly to support the soil mass and 
laundry greywater over it. The soil samples were irrigated with tap water (TW), powdered laundry detergent (Bio Zip) (PLD), and liquid laundry detergent (Dynamo) (LLD) greywater. A measuring cylinder was used to collect drainage water (leachate). The hydraulic conductivity was determined by measuring the total volume of water passing through the soil core within a known time interval (150 min). The saturated hydraulic conductivity was estimated according to Darcy's Law Eq. (1):

$q=\frac{Q}{A t}=\frac{K_{\mathrm{sat}} \Delta H}{L}$,

where, $q$ is the water flux $(\mathrm{cm} / \mathrm{min}) ; t$ is time interval $(\mathrm{min})$; $A$ is cross-sectional area of the soil column $\left(\mathrm{cm}^{2}\right) ; Q$ is discharge rate $\left(\mathrm{cm}^{3} / \mathrm{min}\right) ; K_{\text {sat }}$ is saturated hydraulic conductivity; $\Delta H$ is hydrostatic pressure difference from top to bottom of soil column $(\mathrm{cm}) ; L$ is length of the soil column $(\mathrm{cm})$ and $\frac{\Delta H}{L}$ is hydraulic gradient.

Hydraulic head difference $(\Delta \mathrm{H})=$ Total head at inflow - Total head at outflow.

\section{Soil leachate chemical analysis}

The pH, EC, CEC (the sum of exchangeable cations, Ca, $\mathrm{Mg}, \mathrm{K}$ and $\mathrm{Na}$ ), exchangeable sodium percentage (ESP), and SAR properties of the soil solution (leachate) from the hydraulic conductivity experiments were determined after each experiment. The $\mathrm{pH}$ and $\mathrm{EC}$ were measured using a calibrated $\mathrm{pH}$ meter and an EC meter. An amount of $20 \mathrm{~g}$ of air-dried soil $(<2 \mathrm{~mm})$ was added to $100 \mathrm{~mL}$ of distilled water in a plastic beaker to set up soil water suspensions with a 1:5 soil/water ratio. The determination of CEC, ESP, and SAR was calculated based on Eqs. (2), (3) and (4):

$\mathrm{EC}=\sum$ Exchangeable cations in $\mathrm{me} / 100 \mathrm{~g}$ oven dry soil,

$\mathrm{ESP}=\frac{\text { Exchangeable sodium }}{\mathrm{CEC}} \times 100$,

SAR $=\frac{\left[\mathrm{Na}^{+}\right]}{\sqrt{0.5 \times\left[\mathrm{Ca}^{2+}+\mathrm{Mg}^{2+}\right]}}$.

The macro elements which include $\mathrm{Ca}, \mathrm{Mg}, \mathrm{K}$ and $\mathrm{Na}$ in the soil powder sample were determined using X-ray fluorescence (Model S4 Pioneer) while their concentrations in the irrigated soil were determined using atomic absorption spectroscopy (AAS) (PerkinElmer, model-analyst 800). The elements were extracted from soil leachate according to AOAC method in which $5 \mathrm{~g}$ of soil was mixed with $20 \mathrm{ml}$ of extracting solution and were shaken for $5 \mathrm{~min}$. The samples were then filtered and subjected for AAS analysis.
Table 1 Characteristics of soil collected from Parit Raja, Johor

\begin{tabular}{ll}
\hline Parameter & Percentage $(\%)$ \\
\hline Moisture content & 10.0 \\
Bulk density & 1.36 \\
Liquid limit (LL) & 54.2 \\
Plastic limit (PL) & 38.4 \\
Plasticity index $\left(I_{\mathrm{P}}\right)$ & 15.8 \\
Sieve analysis & Co-efficient of uniform- \\
& ity $=5.9>4$ (well \\
& graded) \\
& Co-efficient of curva- \\
& ture $=0.74$ (clayey \\
& gravelly) \\
\hline
\end{tabular}

Table 2 Classification of soil according to plasticity

\begin{tabular}{lll}
\hline $\begin{array}{l}\text { Plasticity index } \\
\left(I_{\mathrm{P}} \text { or PI }\right)\end{array}$ & Degree of plasticity & Type of soil \\
\hline 0 & Non-plastic & Sand \\
$<7$ & Low-plastic & Silt \\
$7-17$ & Medium plastic & Silty clay or clayey silt \\
$>17$ & Highly & Plastic clay \\
\hline
\end{tabular}

\section{Results and discussions}

\section{Characteristics of soil samples}

The characteristics of the soil collected from the study area are illustrated in Table 1. It can be noted that the soil samples have $10 \%$ of moisture. The "plasticity index" (PI) which indicates the collection of moisture substance over which the soil is plastic was $15.8 \%$. The coefficient of curvature $(\mathrm{Cc})$ was 0.74 ; this value is not in the range 1-3 (AASHTO) standard and indicates that this soil is mostly clayey.

The classification of soil according to plasticity is shown in Table 2 which demonstrates that the soil samples fall into silt clay or clayey silt based on a plasticity index of $15.8 \%$. These findings are in agreement with a previous study conducted by Tjahjanto et al. (2008) which revealed that Parit Rajazone is enclosed by a soft marine clay deposit. The effect of effluent discharge on soil depends on soil properties: for example, silty clay holds water longer than sandy soil, while water is consumed more rapidly by sandy soil (Calkins 2011). 
Fig. $1 \mathrm{pH}$ of soil leachate after irrigated with tap water (TW), powder laundry detergent (PLD) and liquid laundry detergent (LLD) greywater; not irrigated (control)

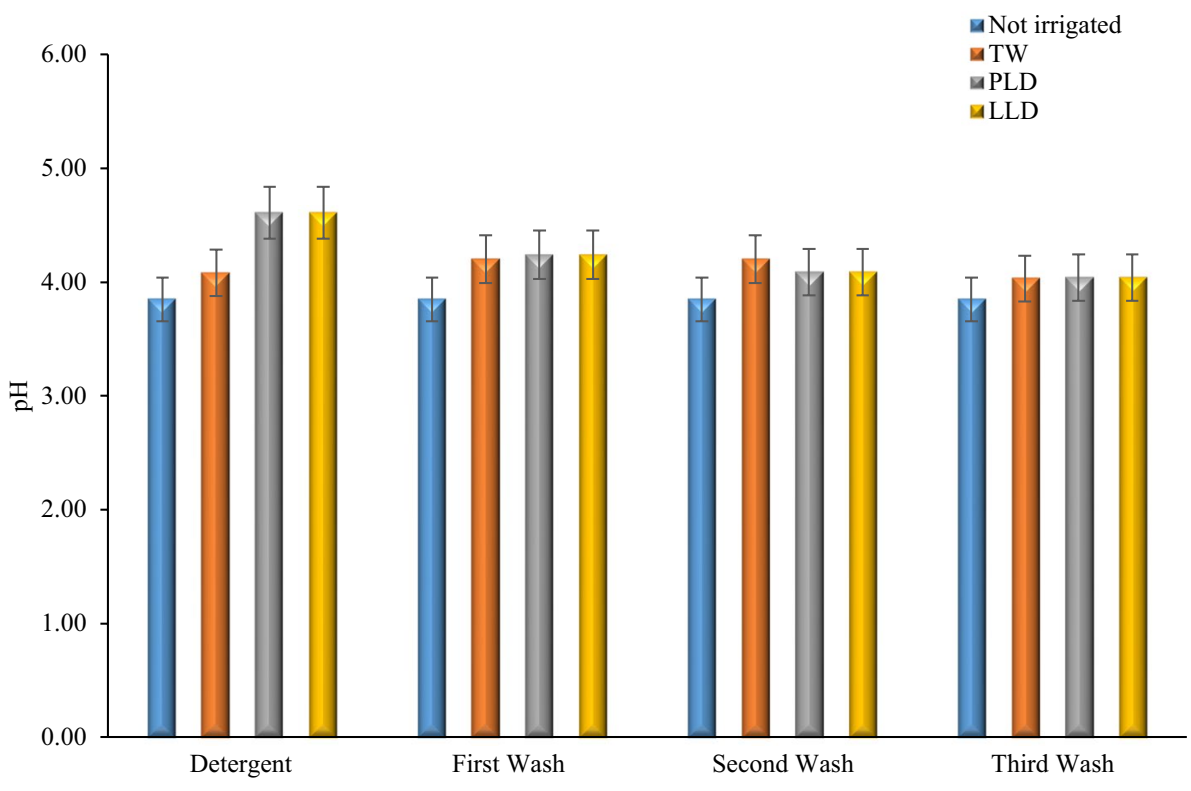

\section{Soil leachate pH and EC after irrigation with laundry greywater}

Figure 1 depicts the $\mathrm{pH}$ of the soil after being irrigated by TW, PLD, and LLD. It was determined that the $\mathrm{pH}$ of soil control (before irrigation with laundry greywater) was $\mathrm{pH}$ 3.85, which indicates deficiency of $\mathrm{Ca}$ and/or $\mathrm{Mg}$ ions in the soil. Calcium survives in soil as transferable $\mathrm{Ca}$ associated with negatively-charged sites on clay mineral surfaces and as structural calcium in mineral crystal lattices. The soil $\mathrm{pH}$ increased from $\mathrm{pH} 3.85$ to 4.72 and 4.61 after irrigation with PLD and LLD, respectively. However, the soil is still acidic. The presence of Na in PLD and LLD as the main content in laundry detergents can potentially increase the $\mathrm{pH}$ level in the irrigated soil. However, the soil $\mathrm{pH}$ might reach alkaline levels by frequently receiving the detergents for a long time. These findings are consistent with the findings reported by Waisel (2012), which indicated that the $\mathrm{Na}$ increased through the dissociation of adsorbed $\mathrm{Na}$ which enhanced the $\mathrm{pH}$ of the soil solution.

The electro-conductivity (EC) of soil control and after irrigation by TW, PLD, and LLD is presented in Fig. 2. The maximum EC was recorded in the soil irrigated with PLD $(174.5 \mu \mathrm{S} / \mathrm{cm})$ and was followed by the soil irrigated with LLD $(152.5 \mu \mathrm{S} / \mathrm{cm})$. The minimum EC was noted in the soil irrigated with PLD and LLD for the third wash laundry (56.4 and $53.5 \mu \mathrm{S} / \mathrm{cm}$, respectively). These results indicate that the EC values decreased with water contain fewer chemicals in detergent. Anwar (2011) studied the effects of reused laundry greywater on local soil in Toowoomba where the EC
Fig. 2 EC of soil leachate after irrigated with tap water (TW), powder laundry detergent (PLD) and liquid laundry detergent (LLD) greywater

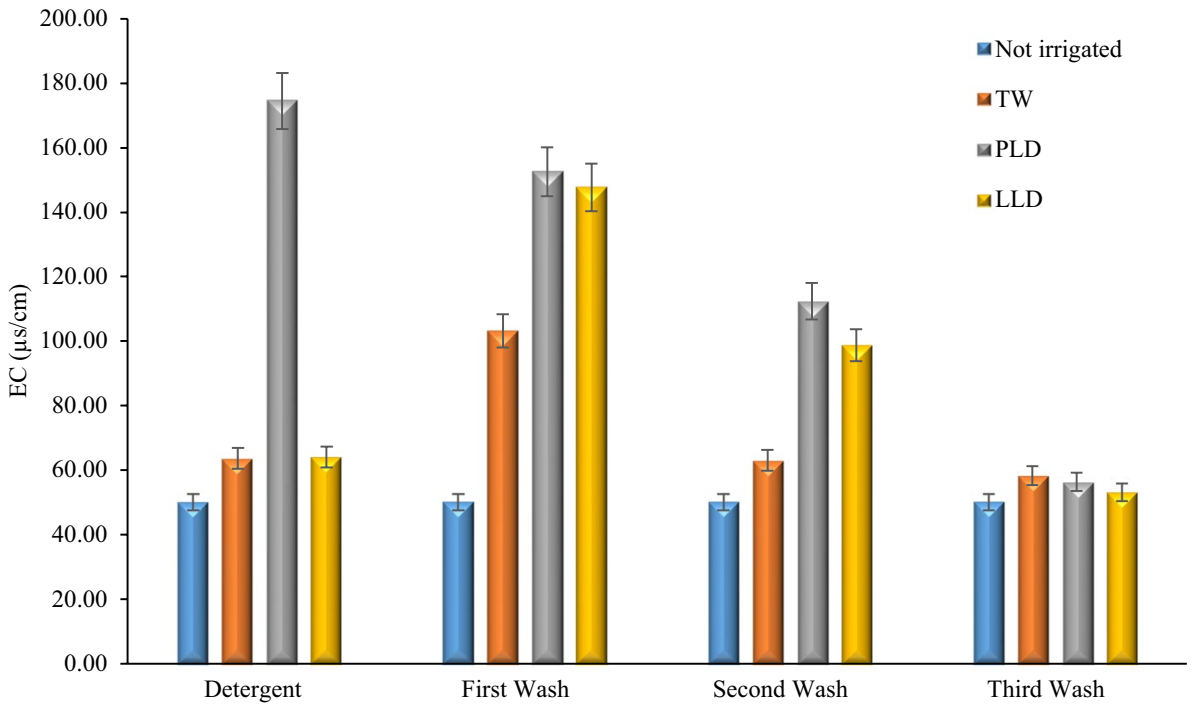


results of soil after irrigation with tap water and laundry greywater were 388 and $752 \mu \mathrm{S} / \mathrm{cm}$, which indicate that the presence of detergents in the water is associated with the increase of soil EC.

\section{Changes of soil saturated hydraulic conductivity $\left(K_{\text {sat }}\right)$}

The saturated hydraulic conductivity $\left(K_{\text {sat }}\right)$ for $10 \mathrm{~min}$ of soil under the irrigation of TW, PLD, and LLD greywater is presented in Table 3. The results revealed that the $K_{\text {sat }}$ reduced after the soil was irrigated with the first wash of PLD and LLD, with $K_{\text {sat }}$ of $7.38 \times 10^{-10} \mathrm{~cm} / \mathrm{s}$ and $7.11 \times 10^{-10} \mathrm{~cm} / \mathrm{s}$, respectively. PLD and LLD irrigation solutions possess high concentrations of salt cations supported by the high EC values, which consequently cause a decrease in the $K_{\text {sat }}$. Soil $K_{\text {sat }}$ relies on the type of soil, porosity, and configuration of the soil pores (Anwar 2011). The clayey type of the soil investigated in this study may influence the infiltration rate which makes it slower. The dispersion of clay particles in Ca soil column leached by $\mathrm{Na}$ and $\mathrm{NaCl}$ aqueous solution led to an irreversible decrease in soil hydraulic conductivity (Yaron et al. 2012). Datnoff et al. (2001) stated that the surface-induced swelling clay is the main mechanism to reduce $K_{\text {sat }}$ in the clay. The main cause of $K_{\text {sat }}$ reduction can be rationalized as a small pore clogging in the soil due to the adsorption of surfactant. Surfactant effects on water infiltration and on percolation in soils are a function of soil type and surfactant characteristics (Kuhnt 1993). Surfactants decrease the capillary rise of water in soil columns when mixed with sands or clayey soils by decreasing water surface tension (Smith and Gillham 1999). This might be caused by swelling of some clay particles which changes the hydraulic capacity of the soil profile and resulted in reduced
Table 3 Mean $K_{\text {sat }}$ for 10 min of soils irrigated with tap water (TW), powder laundry detergent (PLD) and liquid laundry detergent (LLD) greywater

\begin{tabular}{lll}
\hline$K_{\text {sat }}(10$ min $)$ & $\begin{array}{l}\text { Change } \\
\text { from TW } \\
(\%)\end{array}$ \\
\hline $\begin{array}{l}\text { Detergent } \\
\text { TW }\end{array}$ & $\begin{array}{l}\text { 3.18E-09 } \\
\text { LLD }\end{array}$ & -75.77 \\
PLD & $1.11 \mathrm{E}-10$ & -65.07 \\
First wash & & \\
TW & $3.28 \mathrm{E}-09$ & 0 \\
LLD & $7.11 \mathrm{E}-10$ & -78.29 \\
PLD & $7.33 \mathrm{E}-10$ & -77.63 \\
Second wash & & 0 \\
TW & $3.18 \mathrm{E}-09$ & -47.13 \\
LLD & $1.68 \mathrm{E}-09$ & -48.54 \\
PLD & $1.63 \mathrm{E}-09$ & 0 \\
Third wash & & 0.00 \\
TW & $3.23 \mathrm{E}-09$ & -3.13 \\
LLD & $3.23 \mathrm{E}-09$ & \\
PLD & $3.13 \mathrm{E}-09$ &
\end{tabular}

retention of soil water and increased depth of infiltration (Karagunduzet al. 2001; Crites et al. 2014).

\section{CEC, ESP and SAR of soil leachate after irrigation with laundry greywater}

The CEC of soil represents the total amount of cations in the soil which can hold on its assimilation complex and replaced under conditions of $\mathrm{pH}$ and show the capacity of the soils to provide cations. CEC was determined according to the concentrations of $\mathrm{Na}, \mathrm{Ca}, \mathrm{K}$ and $\mathrm{Mg}$ ions. These elements
Fig. 3 Cation exchange capacity (CEC) of soil leachate after irrigated with tap water (TW), powder laundry detergent (PLD) and liquid laundry detergent (LLD) greywater

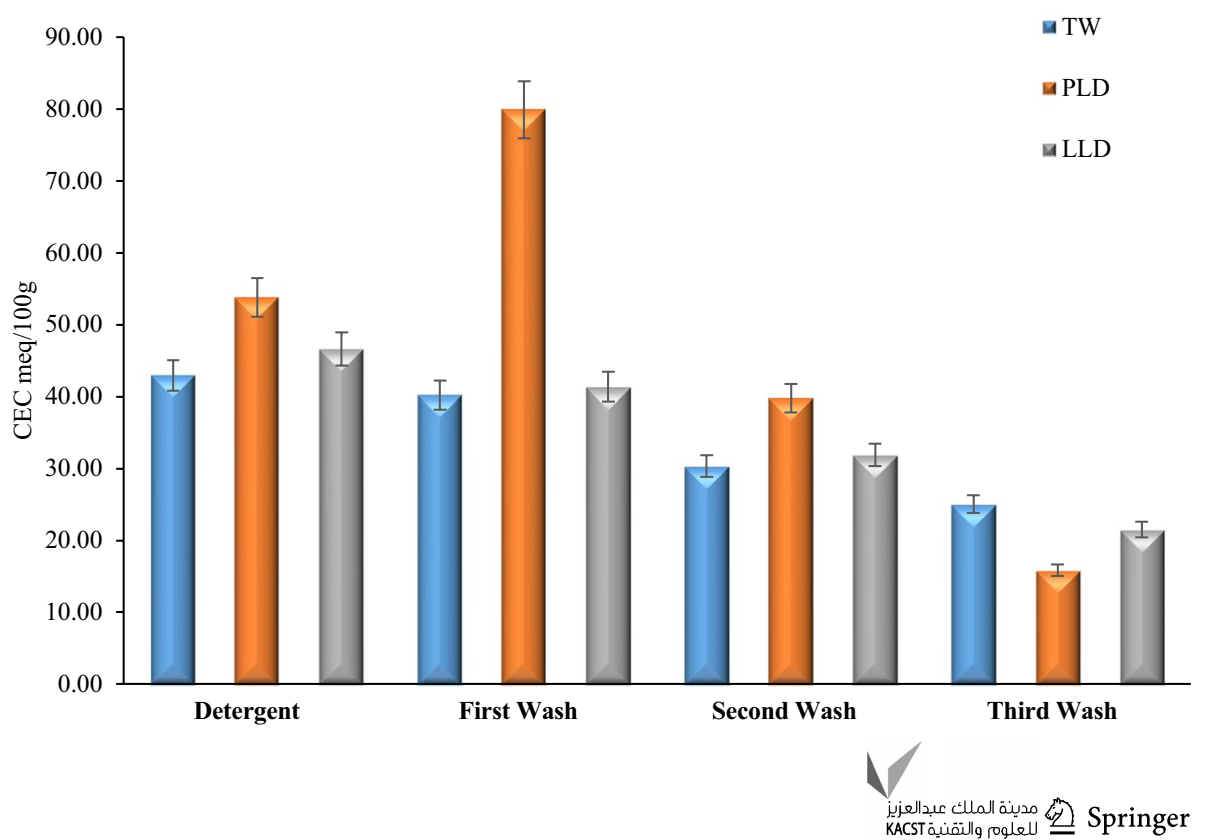


Fig. 4 Exchangeable sodium (ESP) percentage of soil leachate after irrigated with tap water (TW), powder laundry detergent (PLD) and liquid laundry detergent (LLD) greywater

Fig. 5 Sodium adsorption ratio (SAR) of soil leachate after irrigated with tap water (TW), powder laundry detergent (PLD) and liquid laundry detergent (LLD) greywater
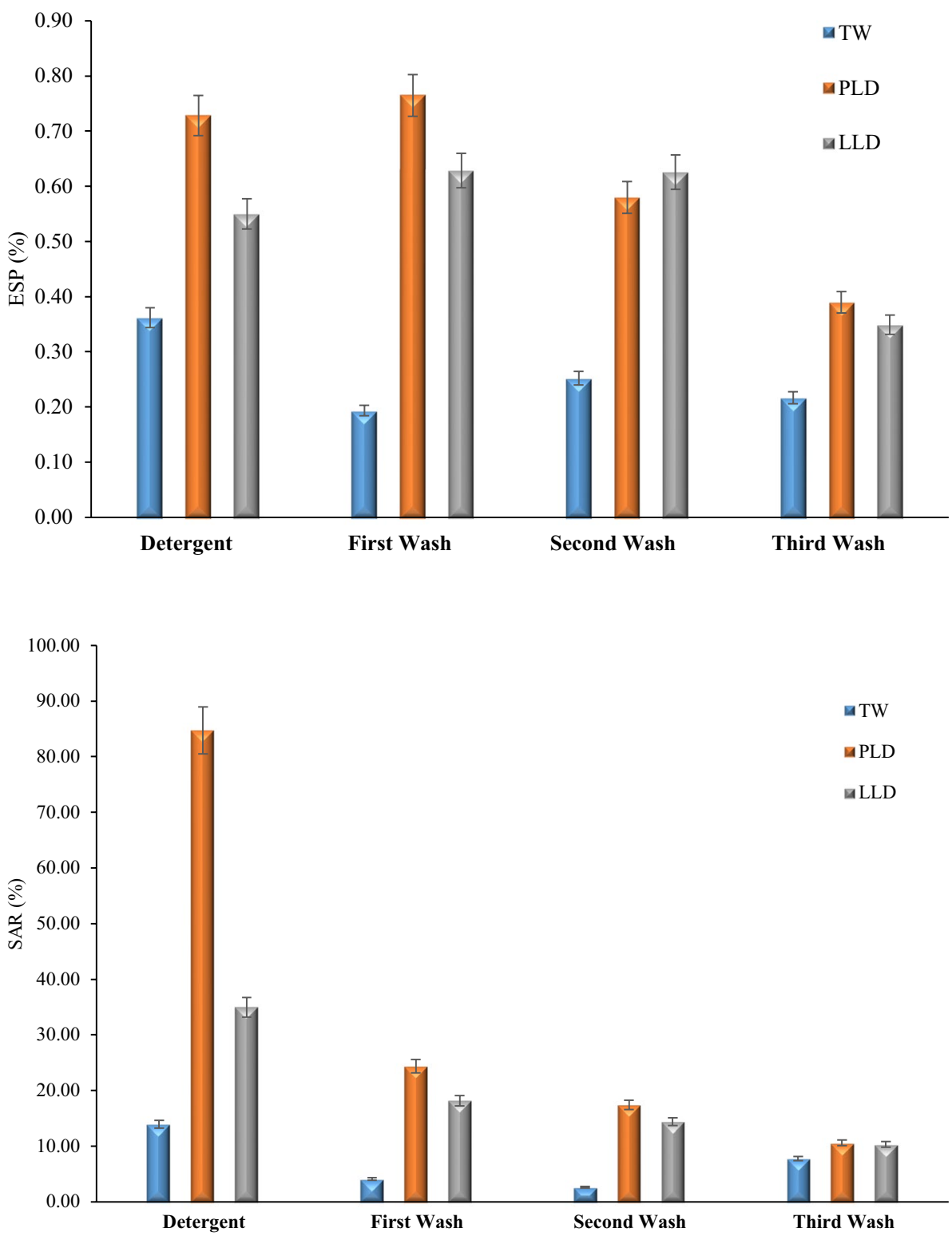

indicate the total amount of exchangeable cations which are removed from the soil using a solution contains a neutral salt held within a given mass of soil. Figure 3 shows that the highest of CEC was found when soil irrigated with first wash PLD of $79.93 \mathrm{meq} / 100 \mathrm{~g}$. Soil CEC after irrigated with PLD and LLD were reduced from first, second and third wash due to the decreases in the concentrations of these cations in the soil with the frequent washing process.

The highest percentage of ESP was recorded in the soil irrigated with first wash PLD $0.76 \%$ and PLD detergent $0.73 \%$ (Fig. 4). These results indicate that the ESP in the irrigated soil has increased compared with the soil irrigated with TP. The presence of high concentration might increase the possibility of sodium toxicity to plants (Skujins 1991). The increase of ESP to more than $15 \%$ which might be caused due to the frequencies irrigation of soil with laundry greywater, the higher levels of exchangeable $\mathrm{Na}^{+}$in soil could cause soil aggregates to crumple due to the spread which leads to poor water access and soil (Wu et al. 2009).

Sodium adsorption on the ratio (SAR) of soil after drainage in four different replicates was subjected to every type of irrigation water. Based on the data presented in Fig. 5, SAR soil was mostly higher in the irrigated soil PLD and LLD where the SARs were 84.69 and $34.97 \mathrm{mg} / \mathrm{L}$, respectively. The SAR in this study was found to be higher than the SAR in laundry greywater of 12.32 studied by Misra and Sivongxay (2009). The recommended value of SAR for reuse of greywater is 4 (ANZECC and ARMCANZ 2000). A higher SAR might lead to the degradation of the soil structure and permeability. Irrigation using water with high SAR may involve soil amendments to avoid long-term damage to the soil such as Ca product topdressing, amendments and 
frequent aeration. Long-term use of raw greywater is estimated to lead to greater negative effects on water penetration into the soil (Travis et al. 2010).

\section{Conclusion}

It can be concluded that the direct discharge of laundry greywater into the soil produces negative effects on the soil properties. The soil $\mathrm{pH}$ and $\mathrm{RC}$ demonstrate a slight increase after irrigation with the first wash PLD and LLD. The infiltration rate and $K_{\text {sat }}$ of the first wash became slower after irrigation with PLD and LLD. High levels of CEC, ESP, and SAR were noted in the irrigated soil with PLD in comparison to LLD. A proper management for greywater should be adopted in order to prevent the destruction of soil composition. The detergents in the laundry greywater ought to be reduced to a minimum concentration which would have no adverse effects on the environment. A new regulation standard for the proper disposal of greywater among developing countries needs to be adopted.

Acknowledgements The authors are thankful for the financial assistance provided by the Malaysian Ministry of Education in the completion of Fundamental Development Research Grant Scheme (FRGS) Vot 1574.

Open Access This article is distributed under the terms of the Creative Commons Attribution 4.0 International License (http://creativecomm ons.org/licenses/by/4.0/), which permits unrestricted use, distribution, and reproduction in any medium, provided you give appropriate credit to the original author(s) and the source, provide a link to the Creative Commons license, and indicate if changes were made.

\section{References}

Abu-Zreig M, Rudra RP, Dickinson WT (2003) Effect of application of surfactants on hydraulic properties of soils. BiosysEng 84:363-372

Anwar AH (2011) Effect of laundry greywater irrigation. J Enviro Res Devel 5(4)

ANZECC, ARMCANZ (2000) Australian and New Zealand guidelines for fresh and marine water quality," National water quality management strategy, Paper no.4. Australian and New Zealand Environment and Conservation Council, Agriculture and Resource Management Council of Australia and New Zealand, Canberra, ACT

Belanger SE, Bowling JW, Lee DM, LeBlanc EM, Kerr KM, McAvoy DC, Christman SC, Davidson DH (2002) Integration of aquatic fate and ecological responses to linear alkyl benzene sulfonate (LAS) in model stream ecosystems. Ecotoxicol Environ Saf 52(2):150-171

Calkins M (2011) The sustainable sites handbook: a complete guide to the principles, strategies, and best practices for sustainable landscapes. John Wiley \& Sons, Hoboken

Chan CM, Norsuhaida K, Mohamed RM (2014) Using a peat media for laundry greywater filtration: geochemical and water quality check. Mid-East J Sci Res 21(8):1365-1370
Crites RW, Middlebrooks EJ, Robert K (2014) Natural wastewater treatment systems, 2nd edn. CRC Press, Italy

Datnoff LE, Snyder GH, Korndörfer GH (2001) Silicon in agriculture, vol 8. Elsevier, Amsterdam

Eriksson E, Auffarth K, Eilersen AM, Henze M, Ledin A (2003) Household chemicals and personal care products as sources for xenobiotic organic compounds in grey wastewater. Water SA 29(2):135-146

Gross A, Wiel-Shafran A, Bondarenko N, Ronen Z (2008) Reliability of small scale greywater treatment systems and the impact of its effluent on soil properties. Int J Environ Stud 65(1):41-50

Jacob K, Wirtschaftsforschung ZE (2005) Lead markets for environmental innovations, edited by PDD hcm W. Springer, Franz

Jakobi G, Lohr A (1987) Detergents and textile washing. VCH Publisher, Weinheim

Karagunduz A, Pennell KD, Young MH (2001) Influence of a nonionic surfactant on the water retention properties of unsaturated soils. Soil Sci Soc Am J 65(5):1392-1399

Kuhnt G (1993) Behavior and fate of surfactants in soil. Environ Toxicol Chem 12:1813-1820

Lange KR (1994) Detergents and cleaners. A handbook for formulators, SchoderDruck GmbH \& Co.KG, p New York

Lazarova V, Asano T (2005) Challenges of sustainable irrigation with recycled water. In: Lazarova V, Bahri A (eds) Water reuse for irrigation, agriculture, landscapes and turf grass. CRC Press, London, pp 1-30

Misra RK, Sivongxay A (2009) Reuse of laundry greywater as affected by its interaction with saturated soil. J Hydrol 366:55-61

Mohamed RM, Chan CM, Ghani H, Yasin M, Kassim AHM (2013a) Application of peat filter media in treating kitchen wastewater. Int J Zero Waste Generation 1(1):11-16

Mohamed RM, Kassim AHM, Anda M, Dallas S (2013b) A monitoring of environmental effects from household greywater reuse for garden irrigation. Environ Monit Assess 185(10):8473-8488

Mohamed RM, Kassim AHM, Anda M, Dallas S (2014a) the effects of elements mass balance from turf grass irrigated with laundry and bathtub greywater. Int J Appl Environ Sci 9(4):2033-2049

Mohamed RM, Wurochekke AA, Chan CM, Kassim AHM (2014b) the use of natural filter media added with peat soil for household greywater treatment. GSTF Int J EngTechnol (JET) 2(4):33-38

Sivongxay A (2005) Hydraulic properties of Toowoomba soils for laundry water reuse. Thesis BEng Environmental, University of Southern Queensland

Skujins J (1991) Semiarid lands and deserts, soil resource and reclamation. CRC Press, New York

Smith JE, Gillham RW (1999) Effects of solute concentration-dependent surface tension on unsaturated fIow: laboratory sand column experiments. Water Res Res 35(4):973-982

Tjahjanto D, Musa S, Ridzuan M, (2008) A study on artificial recharge well as a part of drainage system and water supply in UTHM. In: Proceedings 1st national seminar on environment, development and sustainability (PSISenviro 2008), 28-29 July 2008, Selangor, Malaysia

Travis MJ, Alit W, Noam W, Adar E, Gross A (2010) Greywater reuse for irrigation: effect on soil properties. Sci Total Environ 408:2501-2508

Waisel Y (2012) Biology of halophytes. Academic Press INC, London

Wu L, Chen W, French C, Chang AC (2009) Safe application of reclaimed water reuse in the southwestern United States. UCANR Publications, California

Yaron B, Dror I, Berkowitz B (2012) Soil-subsurface change: chemical pollutant impacts. Springer Science \& Business Media, New York

Ying GG (2006) Fate, behavior and effects of surfactants and their degradation products in the environment. Environ Int 32(3):417-431

Publisher's Note Springer Nature remains neutral with regard to jurisdictional claims in published maps and institutional affiliations

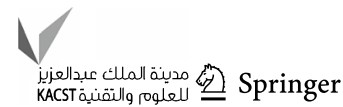

